\title{
Sosyal Medyanın Tüketicilerin Gıda Ürünleri Satın Alma Davranışına Etkisi
}

\author{
Arzu SEÇER 1 \\ Mustafa BOĞA ${ }^{2}$ \\ ${ }^{1}$ Çukurova Üniversitesi, Ziraat Fakültesi, Tarım Ekonomisi Bölümü, 01330, Sarıçam/ADANA. \\ 2Niğde Üniversitesi, Bor Meslek Yüksekokulu, Bitkisel ve Hayvansal Üretim Bölümü, 51700 Bor/Niğde. \\ $\triangle$ : asecer@cu.edu.tr
}

Geliş (Received): 23.12.2016

Kabul (Accepted): 23.02.2017

\begin{abstract}
ÖZET: Günümüzde, sosyal medya çeşitli medya araçları içerisinde sıkça tercih edilmektedir. Bu çalışma da, sosyal medyanın tanımı ve tüketicilerin gıda ürünleri satınalma tercihlerine olası etkileri ortaya konulmuştur. Ayrıca, gıda ürünleri ile ilgili krizlerle karşılaşılması durumunda bu medya kanalının önemi vurgulanmıştır. Çalışmanın ana materyalini daha önce yapılmış çalışmalardan elde edilen ikincil veriler oluşturmaktadır. Sosyal medya, en geniş tanımıyla, kullanıcıların içerik oluşturmalarına ve bu içeriklerin paylaşımına, değişimine, tartışılmasına ve geliştirilmesine olanak veren uygulamalar bütünü olup ortaya çıkardığı yeni norm ve değerlerin etkisiyle ülkeye ve ürün grubuna göre değişen şekilde tüketicilerin satın alma davranışlarını etkilemektedir. Bu noktada işletmeler tüketici eğilimlerini en iyi şekilde takip etmeli ve bu eğilimlere hızlı şekilde cevap verebilme yeteneğine sahip olmalıdır. İşletmeler, pazarlama faaliyetlerini sosyal medyada müşteri ilişkileri yönetimi üzerine yoğunlaştırmalıdır.
\end{abstract}

Anahtar Kelimeler: Sosyal medya, gıda ürünleri, tüketici, pazarlama.

\section{Effects of Social Media on Consumers' Purchasing Behaviours of Food Products}

ABSTRACT: Nowadays, social media has been constantly preferred in many media channels. In this study, definition of social media and possible effects of it on consumers' food products preferences were revealed. Moreover, importance of this media channel has emphasized in case of a crisis related to food products. Main material of the study was secondary data. Social media, in a wide concept, a group of application to provide for users to create their contents and change, share and discuss them. Social media, depending on countries and product groups, effects consumers' purchasing behaviors via reveling new norm and values. In this scope, firms should observe consumers' tendencies to be able to response their demands and focus on customer relationship management in social media.

Keywords: Social media, food products, consumer, marketing.

\section{GÍRIŞ}

Günümüzde işletmecilerin çoğu geleneksel pazarlama kanallarından ziyade dijital pazarlama kanallarını tercih etmektedir. $\mathrm{Bu}$ durum internet reklamcılığını kullanmak amacıyla verilen çabaları artırmaktadır (Chao ve ark., 2012). Aynı zamanda, internet ortamı pek çok kullanıcı için yeni bir bakış açısı ve alış-veriş yapılacak bir ortam olarak görülmektedir. İnternetin gelişimi ile birlikte sanal mağazaların ortaya çıkması, internet ve özellikle sosyal medya kullanıcıları büyük oranda tüketicilere dönüştürmüştür (HenningThurau ve ark., 2004). Kullanicilar evlerinden veya ofislerinden, satın almak istedikleri ürünler hakkında rahatlıkla bilgi sahibi olabilmekte, beğendikleri ürünleri kısa zamanda ve kolaylıkla satın alabilmektedir. Bu durum, ayrı bir pazar ortamının ortaya çıkmasına ve sanal mağazaların yaygınlaşmasında önemli bir rol oynamaktadır. Bu gelişmelerin sonucunda sosyal medya, ürün bilgilerinin elde edilmesini sağlayan ve üreticilerle tüketicilerin buluşarak karşılıklı etkileşim halinde olduğu bir fenomen halini almıştır.

Sosyal medya en geniş tanımıyla, sosyal bir çevre oluşturmak amaciyla kurulan, büyük kitlelerin birbirleriyle etkin olarak iletişime ve etkileşime geçebildikleri elektronik ortamdır (Say, 2015). Bu uygulamalardan Facebook, Twitter, YouTube, Linkedld oldukça yaygın hale gelmiştir. Gün geçtikçe bu medya kanalının çeşitli avanatajları ve dezavantajları ortaya çıkmaktadır. Bu sayede geniş kitlelere ulaşım ve kişilerin gerek birbirleri ile gerekse de firmalarla kolay şekilde bilgi paylaşımı sağlamaktadır. Tüketici farkındalığının artırması söz konusu iken bilgilerin herhangi bir filtrelemeye tabi tutulmadan topluma sunulmas1, olumsuz algının yaratılmasının kolay olması ve bilgi kirliliğine yol açabilmesi gibi olumsuz özellikleri de mevcuttur.

İngiltere merkezli global sosyal medya ajans1 We Are Social yayınladığ 1 "İnternet ve Sosyal Medya Kullanıcı İstatistikleri” başlıklı raporunda 2016 yılının Haziran ayı itibariyle Dünyada ve Türkiye'de internet kullanım alışkanlıklarını ortaya koymaktadır. Bu rapora göre 7,4 milyar kişi olan dünya nüfusunun \%46's1 (3,4 milyarı kişi) aktif internet kullanıcısı, \%31'i (2,3 milyar kişi) ise sosyal medya kullanıcısı olduğu belirtilmektedir. Dünyada yaygın bir şekilde tercih edilen sosyal ağlar sirasiyla Facebook (\%21,4), Whatsapp (\%12,1), Facebook Messenger $(\% 10,8)$, Tumblr $(\% 7,5)$ ve Instagram'dır $(\% 5,4)$. Türkiye nüfusu ise 79,1 milyon kişi olup bunun içerisinde aktif internet kullanıcıların oranı \%58 (46,3 milyon kişi) ve sosyal medya kullanıcıların oranı \%53'dür (42,0 milyon kişi). Türkiye'de tercih edilen sosyal ağlar sırasıyla Facebook (\%32), Whatsapp (\%24), Facebook Massenger (\%20), Twitter (\%17) ve Instagramdır (\%16). En fazla tercih edilen sosyal ăg olan Facebook kullanıcılarının \%36,0'1 20-29, \%23,0'1 30-39 yaş arasındadır (Kemp, 2016).

Son yıllarda yapılan pek çok çalışmada, sosyal medyanın, yeme-içme, giyinme, seyahat, eğlence gibi 
pekçok alanda kullanıcıların eğilimlerinin ve tercihlerinin bu alanın gelişmesinde etkilerinin olduğu ifade edilmektedir (Yücel, 2013; Sema, 2013; Paquette, 2013; Y1ld1z, 2014; Toksar1 ve ark., 2014; Shabnam ve ark., 2014; Ioanas ve Stoica, 2014; Algül ve Sütçü, 2015; Say, 2015; Olgun, 2015). Tüketicilerin gıda ürünleri satın alma davranışını ve geleceğe yönelik beklentilerini ortaya koymak uzun vadeli pek çok tahminde bulunulmasına ve doğru pazarlama stratejilerinin oluşturulmasına katkı sağlayacaktır. Bu nedenle yapılan bu çalışmada sosyal medyanın tanımı ve tüketicilerin gıda ürünleri satınalma tercihlerine olası etkileri daha önce yapılmış çalışmalardan derlenerek ortaya konulmuştur. Ayrıca, gıda riski ile karşılaşılması durumunda bu medya kanalının önemi vurgulanmıştır. Çalışmanın ana materyalini daha önce yapılmış çalışmalardan elde edilen ikincil veriler oluşturmaktadır.

\section{Sosyal Medyanın Tanımı ve Gelişimi}

Sosyal medya kavramını tam olarak tam olarak ortaya koyabilmek için öncelikle temelini oluşturan Web 2.0 uygulamalarını tanımlamak gerekmektedir. Web 2.0, 2004'de kullanılmaya başlayan bir sözcük olup, ikinci nesil internet hizmetlerini ifade etmektedir. $\mathrm{Bu}$ uygulamalar, internet kullanıcılarının ortaklaşa ve paylaşarak yarattığ 1 sistemi tanımlamaktadır (örneğin toplumsal

siteleri, vikiler, iletişim araçları, folksonomiler)

(Vikipedi, 2016). Böylece, Web 2.0 kolay bir şekilde bilgi paylaşımı için kullanılır iken, interaktif iletişim, birlikte çalışma ve işbirliği imkanı da sağlayarak başka bir yapıya dönüşmüştür (Kaplan ve Haenlein, 2010).

Sosyal medya, araştırmacılar tarafından çeşitli şekillerde tanımlanmıştır. Jantcsh (2008), sosyal medyayı "kullanıcılar tarafından yaratılan değerlerin sosyal etkileşimle paylaşımı için teknolojinin kullanımı" olarak görmektedir. Dykeman (2008) bu tanımı biraz açarak "kullanıcıların dijital ve yaratıcı içerik oluşturması, gerçek zamanlı tartışmalar yapması ve geri besleme alması, önerilerde bulunması ve değerlendirme yapması için kullandıkları bir araç" olarak ifade etmiştir. Parr (2010), bu terim için kısaca "bilginin ve deneyimlerin etkin bir şekilde paylaşımı için elektronik araçların ve internetin kullanımı" şeklinde bir tanım yapmıştır. Kaplan ve Haenlein (2010) ise sosyal medyayı en geniş şekilde "kullanıcı tarafindan oluşturulan içeriklerin olușturulmasına ve değiștirilmesine izin veren, ideolojik ve teknolojik olarak Web 2.0 tabanlı işlemlere dayanan bir grup internet uygulaması" olarak tanımlamaktadır. Özetle sosyal medya, kullanıcıların içerik oluşturmalarına ve bu içeriklerin paylaşımına, değişimine, tartışılmasına ve geliştirilmesine olanak veren uygulamalar bütünüdür.

Sosyal medya ve sosyal ağ siteleri pek çok kaynakta birbiri yerine kullanılan kavramlar haline geliştir. Ancak tanımları birbirinden farklıdır. Sosyal medya, geniş bir kullanıcı kitlesi tarafından öncelikli olarak bilgi paylaşımı ve yayılması için kullanılan bir medya aracı iken; sosyal ağ siteleri ortak ilgi alanına sahip insanların birlikte hareket etmesi ve topluluk oluşturabilmeleri için kullanılan uygulamalardır (Cohen, 2009; Hartshorn, 2010).

1990’lı yılların sonlarında internet oldukça popüler hale gelmişti. İçeriklerin kullanıcılar tarafindan oluşturulması ve yayınlanması yaygınlaşmaya başlanmıştır. İlk sosyal ağ sitesi (SixDegrees.com) 1997 yılında oluşturulmuştur. 2002 yılından bu yana, pek çok sosyal ağ sitesi ortaya çıkmıştır. Bu sitelerden bazıları oldukça popüler iken, bazıları ise başarısız olmuştur. 2000'li yılların sonlarında, sosyal medya geniş ölçüde kabul görmüş ve bazı siteler çok fazla sayıda üyeye sahip olmuştur (Dewing, 2010).

Sosyal medyanın online yada mobil olmak üzere sosyal ağ siteleri, bloglar, firmalar tarafından desteklenen tartışma siteleri, sohbet odaları, tüketici mailleri, tüketicilerin ürünlere ve hizmetlere oy verdikleri siteler gibi pek çok şekli bulunmaktadır (Hollesen, 2010). Bu ağların en yaygınları Facebook, Twitter, Youtube, Linkedld, Google+, Pinterest ve Flickr olarak stralanabilir.

Sosyal medyanın oldukça hızlı şekilde büyümesi tüm dünyada pazarlamacıların ilgisini çekmiştir. Pazarlamacılar sosyal medyayı, "pazarlama mesajlarını tüketicilere ulaştırmak ve ağızdan-ağıza pazarlama yöntemlerini kullanarak onlarla diyaloga girmek için bir potansiyel araç" olarak görmüştür (Cvijkj ve Michahelles, 2013). Günümüzde sosyal medya reklamcılığı üzerine yapılan harcamalar giderek artmakta ve geleneksel pek çok iletişim aracından vazgeçilerek tüketicilerle birebir iletişime geçilmektedir. Dünyada sosyal medya reklamcılığı üzerine yapılan harcamalar 2014 yılında 16,10 milyon \$ olarak gerçekleşmiş ve bir önceki yıla göre \%45,3 artış göstermiştir (Cmocouncil, 2015).

\section{Sosyal Medya Pazarlamasının Tanımı ve Önemi}

Sosyal medya oldukça hılı şekilde büyümekte ve tüm kullanıcılar tarafindan yoğun ilgi görmektedir. Sosyal ağlar kuruluş itibariyle sosyal paylaşımları desteklemek, arkadaş edinmek veya mevcut arkadaşlıkları güçlendirmek amacıyla kurulsa da, sonrasında bu amacı aşarak pazarlama dünyasının önemli araçlarından birisi haline gelmiştir. İşletmeler için sosyal medya, geleneksel aracıları ortadan kaldırmış ve firmalar ile tüketicilerin doğrudan iletişim kurmalarına olanak sağlamıştır. Bu sebepten dolayı -Starbucks gibi dev gıda şirketlerinden yerel dondurma mağazalarına kadar hemen hemen tüm işletmeler sosyal medya pazarlamasına oldukça önem vermektedir. Birkaç yıl öncesine kadar işletmeler sosyal medya hakkında çok az bilgi sahibiyken, su anda hılı bir şekilde sosyal medya pazarlamasına adapte olmaktadır (Neti, 2011). Bir başka ifadeyle, işletmelerin tüketicilere yaklaşımları ve iletişimde kullandıkları araçlar sosyal medyanın ortaya çıkışı ile büyük ölçüde değişmiş ve pazarlama stratejilerinde sosyal medya pazarlaması önemli bir yer almıştır.

1. Sosyal medya pazarlaması "markalarla tüketiciler arasında kişisel bir kanal, sosyal etkileşim ve kullanıcı odaklı değerler ağı oluşturularak kurulan bağ" 
olarak tanımlanmaktadır (Chi, 2011). Özgen ve Doymuş (2013) ise bu kavramı "bireyleri online sosyal kanallar yoluyla kendi web sitelerini, ürünlerini ya da hizmetlerini tanıtmak ve geleneksel reklam kanallarıyla ulaşılması mümkün olmayan çok geniş topluluklarla iletişim ve bağlantı kurulmasına olanak sağlayan bir süreç" olarak ifade etmektedir. Başka bir ifadeyle, bir firmanın sunduğu ürünleri yada hizmetleri pazarlayabilmeleri için tüketicileri ikna etmek amacıyla sosyal medyanın kullanılması için yapılan çabalar bütünüdür. Firmanın etkisini, ününü ve markasını mevcut ve potansiyel müşterileri arasında güçlendirmek için sosyal ağlarda yürüttüğü stratejik ve metodolojik süreçtir. İşletmeler tüketici nazarında farklılaşma, marka imajının güçlenmesi, marka bağlılığı oluşturma ve ürünlerini konumlandırma amacıyla yoğun çabalar vermektedir. Sosyal medya pazarlamasının işletmelere daha birçok faydası bulunmaktadır. Sosyal medya pazarlaması, işletmelere potansiyel tüketicilerle iletişim kurma, samimiyet duygusunu güçlendirme ve önemli ilişkilerin geliştirilmesi için bir fursat sunmaktadır. Bu mevcut ve potansiyel müşteriler ile firma çalışanları için geçerlidir. Eğer bir firma sosyal ağlarda samimi tavır sergileyebiliyorsa pek çok kişi tarafından daha çok dikkat çekmektedir

2. İşletmeler sosyal medya araçlarını kullanarak personel giderlerini ve dolayısıyla pazarlama masraflarını azaltmakta ve karlarını artırabilme imkânı bulmaktadir.

3. İşletmeler bilgi ve deneyimlerini paylaşabilmekte, tüketici bilgilerine erişebilmekte, tüketicilerin birbirlerine yardım etmesini sağlayabilmekte ve tüketicilerin beklentilerine uygun pazarlama stratejilerinin geliştirilmesine olanak sağlayacak veriler elde edebilmektedir (Neti, 2011).

4. Firma yöneticileri ve çalışanlar arasında açık iletişim vaat eder,

5. Çalışanların bilgi ve deneyimlerini paylaşarak, proje fikirlerini ve etkin bir şekilde takım çalışması sağlamalarına olanak sağlar,

6. Basit metinler yerine, görüntülü ve sesli yayınlar yapılmasına olanak sağlar,

7. Geribildirim, ürün tanımlama, ürün geliştirme ve müşteri hizmetleri konularında mevcut yada potansiyel müşterilerin birbirleriyle işbirliği yapmalarına olanak sağlar,

8. Firmanın çalışanlarını ve diğer paydaşları iyi organize edilmiş bir grubun üyeleri olmak için destekler,

9. Tartışmalar için ortam oluşturur

Sosyal medya pazarlamasının yaygınlaşmasıyla beraber online tüketici kavramı da önemli hale gelmiştir. Online tüketiciler; geleneksel tüketiciden daha bilinçli ve sanal ortamı kullanma tecrübesine sahip, bilgi teknolojilerini kullanan, teknolojik gelişmeleri takip eden, risk alabilen, kendine en uygun ürünü, en iyi fiyatla ve en kısa zamanda bulmaya çalışan ve memnuniyetlerini ya da memnuniyetsizliklerini sosyal ağlarda hızlı bir şekilde paylaşan kişilerdir (İşler ve ark., 2014).

Tüketicileri sosyal medyadan bilgi almaya yönlendiren ve internet üzerinden alışveriş yapmalarına sebep olan temel unsurlar; zamandan tasarruf etmek, en uygun fiyata ulaşmak, istek ve ihtiyacı doğrultusunda kendisine en uygun ürünü bulmak olarak sıralanabilir (Punj, 2011). Bununla birlikte online alışverişin tüketiciler açısından geleneksel alışveriş ortamlarında karşılaşılabilecek mağaza kalabalığı ile kuyrukta bekleme gibi problemler yaşanmaması, saat kısıtının olmaması, alışveriş esnasında rahatlık ve kolaylık yaşanması ve geniş bir ürün yelpazesi ile karşılaşılması gibi birçok avantajları da bulunduğu bilinmektedir. Geleneksel alışverişte ürünü ya da hizmeti ödemesini yaparak satın alan tüketici sorumluluk altına girerken, online alışverişte satın alma işleminin tamamlanmasına kadar her aşamada ve satın aldıktan sonra belirtilen süre içerisinde ürünü çok rahatlıkla iade şansına sahiptir (Kırçova, 2008).

$\mathrm{Bu}$ doğrultuda, sosyal medya reklamcılığı da gün geçtikçe önemli bir hal almaktadır. Sosyal medya reklamcılığı bir mal, fikir veya hizmetin tanıtımı için düzenli ve planlanmış mesajları içermektedir. Reklamların müşteri merkezli olmasına özen gösterilmektedir. Müşteriler ile kurulacak en ufak iletişim oldukça önemlidir, çünkü reklamların başarıya ulaşıp ulaşmayacağına karar verecek olanlar müşterilerdir. Sosyal medyada reklam vermenin avantajlarından bazıları; hedef kitle tarafindan marka, fikir veya hizmetin hızlı ve kolay şekilde tanıtılmasını sağlar, hedef kitlenin pazara sunulan yeni ürünlerle ilgili bilgi edinmesine yardımcı olur ve marka ile müşterisini sürekli olarak iletişim halinde tutar (Vukasovič, 2013).

\section{Sosyal Medyanın Gıda Ürünlerinde Tüketici Davranışlarına Etkisi}

Sosyal medya üzerinde pazarlamaya konu olan onlarca ürün grubu içerisinde gıda ürünleri, tüketicileri doğrudan etkileyen, geniş kitleler üzerinde etkisi olan ve pek çok sosyo-ekonomik ve demografik faktörün etkisi altında olan bir ürün grubudur. Sosyal paylaşım sitelerinde arkadaşlarla, aileyle yada meslekdaşlarla yenilen yemeği paylaşmak yaygın bir davranış halini almıştır. Yemek yenilen pek çok yerin sosyal bir içerikte verilmesi, yeme alışkanlıklarını etkilemektedir. Son yıllarda yapılan pek çok araştırma sosyal medyanın tüketicilerin gıda ürünleri satın alma sürecini (ihtiyacı görme, seçenekleri aramak ve değerlendirmek, satın alma, deneyimi değerlendirme ve geri bildirimi sağlama), eğilimini ve tercihlerini çeşitli şekillerde etkilediği ifade etmektedir. Başka bir ifade ile sosyal medyanın tüketici davranışları ve motivasyonları üzerine çeşitli şekiller ve düzeylerde etkileri olduğu görülmüştür.

Dünya Sağlık Örgütü (2013), yapmış olduğu bir araştırmaya göre gıda işletmelerinin gençlere ve çocuklara ulaşmak için pazarlama stratejilerinde çeşitli medya kanallarını kullandıklarını ve sosyal medyanın bu medya kanallarını içerisinde önemli yer aldığını ifade etmektedir. Sosyal medya firmalara bilgi sağlama ve hedef kitle için pazarlama stratejilerini tekrar düzenlemek için diğer medya kanallarına göre daha fazla olanak sağlamaktadır. Sosyal ağ siteleri özellikle gençler ve çocuklar arasında oldukça yaygın olarak 
kullanılmaktadır. Sosyal medya pazarlaması hatırlatma reklamları, ürün veya marka farkındalığı ve satın alma niyeti üzerine olumlu etkileri bulunmaktadır.

Kenly ve Poston (2011) firmaların yeni ürün geliştirme sürecine sosyal medyanın etkisini ortaya koymak amaciyla 90 gida imalatcisı firma ile derinlemesine mulakat yoluyla bilgi almıştır. Çalışmada, görüşülen firmaların yarısından fazlası, sosyal medyayı oldukça yoğun şekilde kullanmasına rağmen, bazıları hala az sayıda ürünle bu medya kanalını deneme sürecindedir. Firmalara göre, yeni ürün geliştirmede sosyal medya kullanımı, işletmelerin daha fazla kar elde etmesini, ürünün pazara daha hızlı şekilde sunulmasını ve ürün maliyetinin daha düşük olmasını sağladığı vurgulanmaktadır. Sosyal medyanın sağlamış olduğu bu faydalar daha yüksek pazar payına ve ürün gelirlerinin artmasına sebep olmaktadır. Firmalar yeni ürün geliştirme ve pazarlama stratejilerini belirlemede tüketicilerle karşılıklı olarak bilgi alışverişinde bulunduklarını vurgulamışlardır.

Fransa ve İsviçre'de 2014 yılında yapılan bir çalışmada sosyal medyanın 15-36 yaşları arasındaki tüketicilerin gıda ürünleri tüketim alışkanlıklarına etkileri incelenmiştir. Görüşülen kişilerin \%81'i ayda en az altı defa genellikle sosyalleşmek ve özel günlerini kutlamak için restaurantları ziyaret etmektedir. Bu kişiler gidecekleri restaurantlar hakkında bilgi almak için genellikle yakın çevrelerinin tavsiyelerini ve işletmelerin web sayfalarındaki bilgileri dikkate almakta, az sayıda kişi (görüşülen kişilerin \%20'si sıklıkla sosyal medyadan faydalanmaktadır) ise sosyal medyayı kullanmaktadır. Büyük oranda 29 yaşın üzerindeki tüketiciler sosyal medyadan bilgi almaya daha fazla meyillidir. Tüketiciler sosyal ağlarda genellikle yemek çeşitleri, fiyatlar, menü ve restaurantın genel atmosferi hakkında bilgi sahibi olmak istemekte olup promosyonlara ve diğer tüketicilerin görüşlerine önem vermemektedir. Bu kişiler, deneyimlerini sosyal medyada görüşlerini paylaşmaya meyilli olmayıp, deneyimlerini anlatarak paylaşmaktadır. Sosyal medyada en fazla kullanılan uygulamalar ise bir restaurantı takip etmek yada beğenmek, fotoğraf yada videoları paylaşmak veya restaurant sayfalarına tavsiyelerde bulunmak şeklindedir. Ayrica, tüketicilerin sosyo-demografik özellikleri (yaş,eğitim ve çalışma durumu) ile sosyal medya kullanım alışkanlıkları arasında da pozitif ilişki bulunmuştur (Meier ve ark., 2014).

Bir İngiliz Araştırma Şirketi olan Brandwacth, 2015 yılında, tüketicilerin gıda ve içecek sektöründe sosyal medya kullanımlarını ve eğilimlerini ortaya koymaya yönelik bir rapor hazırlamıştır. Raporda bu sektörde tüketicilerin isteklerinin, tercihlerinin ve eğilimlerinin hızla değiştiği ve böyle değişken bir alanda işletme sahiplerinin ve diğer paydaşların tüketicilerle ilgili geniş bilgi sahibi olmasının değişikliklere daha çabuk adapte olunması için gerekli hale geldiği vurgulanmıştır. Sektördeki pek çok büyük ölçekli işletme ise bunu fark etmiş ve gün geçtikçe sosyal medyayı takip etmeye daha fazla önem vermiştir. Dünyada en fazla üye sayısına sahip olan sosyal medya aracı Facebook'ta bu sektörün önde gelen restaurantlarının etkili kampanyalar yürütmekte, kullanıcılar günde 1,55 paylaşım, 4.753,36 beğeni ve 134,24 yorum yapmaktadır. Bu rakamlar kullanıcıların sosyal medyanın bilgi yayma avantajından yararlandıklarını göstermektedir. $\mathrm{Bu}$ şekilde yapılan yorumların çoğu işletmeler tarafından yanıtlanmaktadır. Benzer bir şekilde farklı araştırıcılar tarafından marka ve tüketici arasında güçlü ve değerli bir bağ oluşturabilmek için temel unsur, interaktif ve karşılıklı iletişim kurmak olduğu belirtilmiştir (Brandwatch, 2016).

Nyarkoa ve Altıntaş (2015) yılında yapmış oldukları çalışmalarında Ghana'da gıda sektörünün çeşitli paydaşlarıyla (tüketiciler, üreticiler ve araştırmacılar) görüşmeler yaparak Ghana'da sosyal medyanın gıda endüstrisinin etkinliğini ve tüketici davranışlarına etkisini ortaya koymuştur. Ghana'da sosyal medya pazarlamasıyla ilgili ortak görüş sosyal medyanın dünyanın her yerinden firmaları ve tüketicileri bir araya getiren, maliyeti düşüren ve firma karını artıran bir pazarlama kanalı haline dönüştüğüdür. Çalışmada firmaların sosyal medya sayesinde rakip firmalara karşı avantaj sağlayarak pazar paylarını ve uzun vadede müşterilerin marka bağlılığını artırdıkları vurgulanmıştır.

Alyakut (2016) çalışmasında Kocaeli'nin Kartepe ilçesinde doğal gıda üretimi ve satışı yapan kadınlarla görüşerek sosyal medya kullanım düzeylerini belirlemiştir. Araştırma kapsamında kadınların sosyal medya kullanmaya bu konuyla ilgili kişilerin tavsiyeleri ile başladıkları ve kullanmaya başladıkları ilk dönemlerde çevrelerinden yardım aldıkları belirlenmiştir. Sonraki dönemlerde ise hem içerik oluşturmak hem iletişim kurmak için kendileri çaba görtermişlerdir. Sosyal medyayı öncelikle tanıtım yapmak, buna ek olarak bilgi alışverişi ve sipraiş almak amacıyla kullanılmaktadır.

Kızgın ve Özkan (2014), çalışmasında Türkiye'de farklı bölgelerde yaşayan tüketicilerin helal gıda tüketim eğilimlerini belirlenmek amacıyla internet üzerinden yaptığı anket çalışmasıyla belirlemiştir. Çalışmada tüketicilerin helal gıda tüketimini etkileyen önemli faktörlerden birisinin de sosyal medya kullanımı olduğunu ortaya koymuştur.

PwC (2013) tarafindan toplam 11 ülkede (ABD, Kanada, Brezilya, Rusya, Hollanda,İngiltere, Almanya, İsviçre, Fransa, Çin ve Türkiye) yapılan araştırmada tüketicilerin sosyal medya kullanım alışkanlıkları ortaya konulmuş ve geleceğe yönelik bazı tahminlerde bulunulmuştur. Araştırma kapsamındaki tüm ülklerde katılımcıların yaklaşık yarısı günlük olarak sosyal medya sitelerini ziyaret etmekte iken Türkiye'de bu oran \%69'dur. Kullanıma oranla sosyal medya üzerinden alışveriş yapma oranı düşük gözükse de küresel anket sonuçları ile kıyaslandığında Türkiye'de sosyal medya üzerinden alışveriş yaptığını belirtenlerin oranı diğer ülkelere oranla daha yüksektir. İnternet üzerinden alışveriş yapanlar temel olarak, sevdikleri markaları takip etmekte, bildikleri firmalar ve ürünler hakkında yorum yapmakta ve yenilerini keşfetmektedir. Katılımcılar belirlenmiş ürün gruplarının tamamında benzer oranlarda bilgi edinmek ve başkalarının deneyimleri öğrenmek 
amacıyla internette araştırma yapmaktadır. Bu kişiler alışveriş yaparken kitap-müzik, elektronik, kozmetik ve beyaz eşyada büyük oranda sadece interneti; giyim, mobilya ve gıdada büyük oranda sadece mağazaları tercih etmektedir.

Deloitte firması tarafindan 2014 yılında İngiltere'de yapılan bir araştırmada son yıllarda tüketicilerin satın alacakları gıda ürünlerine karar verirken geçmişe göre daha fazla etkili oldukları ve diğer tüketicileri etkileme yeteneklerinin de daha fazla olduğu vurgulanmıştır. Bu araştırmaya göre, sosyal ağların ve dijital araçların kullanımının artmasıyla, tüketiciler giderek artan şekilde nerede, nasıl ve ne zaman ürün elde edeceklerini kendileri belirlemektedir. Böylece tüketiciler daha kişisel hizmetler talep etmekte, tüketecekleri malların ve hizmetlerin özelliklerini belirleme şansına sahip olmayı istemektedir. Sosyal medya sayesinde tüketiciler düşüncelerini deneyimlerini paylaşarak tüketimlerini şekillendirmekte geleneksel yöntemleri terk etmektedir. $\mathrm{Bu}$ durum, tüketicilerin beklentileri ile tüketicilerin bu beklentileri karşılamaları arasında bir boşluk oluşmaktadır.

Olgun (2015), Aydın ilinde lisans düzeyinde öğrenim gören kişilerle yaptığı çalışmasında sosyal medyanın tüketicinin satın alma davranışına etkisi belirlemiştir. Katılımcıların sosyal medyayı kullanım amaçları sirasıyla moda ve giyim $(\% 43,8)$, spor $(\% 17,6)$ ve kitaplar ve dergilerdir. Bu kişilerin oldukça düşük bir bölümü gıda ve içecek sektörü $(\% 8,2)$ hakkında bilgi almak için sosyal medyayı kullanmaktadır. Bu konuda sosyal ağları kullanan tüketicilerin $\% 58,8$ 'i bayan olarak belirtilmiştir. Görüşülen kişilerin \%70,4'ü sosyal medyadan birçok kez ürün satın aldıklarını, \% 62,4’ü sosyal medyada yapılan yorumların ürün satın alımını etkilediğini ve \%60,8'i ise satın aldıkları ürünü sosyal medyada paylaştıklarını ifade etmişlerdir

2012 yılında Amerika Birleşik Devleri'nde (ABD) yapılan bir çalışmada tüketiciler sosyal medyayı sırasıyla gıda deneyimlerini paylaşma, gıdalarla ilgili tavsiyeler alma ve yalnız yemek yerken oyalanma amaciyla kullanmaktadır. Tüketicilerin beslenme alışkanlığı önceki yıllarda aile gelenekleri ve etnik köken tarafından belirlenmekte, yakın çevredeki alış-veriş birimleri tercih edilmekte ve yemek tarifleri aile büyüklerinden yada yemek kitaplarından alınmaktaydı. Günümüzde ise medya, restaurantlar, markalar ve yeni tatlar tanitnakta, gıdalar çoklu kanallardan yada online olarak satın alınabilmekte, tarifler ise televizyon programlarından, web sitelerinden, bloglardan veya online videolardan alınmaktadır. ABD'de yaşayan 18-64 yaş arasındaki 194,5 milyon yetişkin nüfusun \%49'u sosyal ağlar, \%40'1 web siteleri veya bloglar vasitasıyla gidalarla ilgili bilgi almaktadır. Sosyal medya tüketicilerin beslenme alışkanlıklarını belirlemede önemli bir unsur haline gelmiştir. Sosyal medyanın yaygınlaşmasından önce ekonomik ve yüksek fayda sağlayan ürünler tercih edilirken, bugün, eğlence, farklı deneyimler edinme, kalite, çeşitlilik ve tüketici memnuniyeti ön plana çıkmıştır. Sosyal medya tüketicilere sadece görüntüler ve hikayeler ile duyusal deneyimleri hayal etme ve gida hafızasının yeniden oluşturulması için bir çevre imkanı sunmaktadır. Aynı zamanda yeni gidalara daha kısa zamanda ulaşabilme imkanı sunmakta, özelliklerinin daha ayrıntılı ve yakından tanıma firsatı sunarak arzulanan bir hale getirmektedir.

Murphy ve Wright (2015), yılında İrlanda'da yaptıkları çalışmalarında büyük işletmelerin küçük ve orta büyüklükte işletmelere göre sosyal medyaya adapte olmakta daha avantajlı oldularını ifade etmişlerdir. Küçük ve orta büyüklükte işletmeler kullanıcıların dikkatini çekmek için hedef kitlenin beklentileri doğrultusunda doğru mesajların ve ifadelerin seçilmesi, zengin içeriklerin oluşturulması, görsellerin ve videoların kullanılması tüketicilerin dikkatini çekmek için oldukça önemlidir.

Say (2015) çalışmasında Türkiye'de gıda sektöründe faaliyet gösteren ve Facebook sayfalarını aktif şekilde kullanan firmaların pazarlama bölümü yetkilileri ile görüşmeler yapmış ve Facebook kanalı ile yapılan pazarlama faaliyetlerinin tüketiciler üzerindeki etkilerini ölçmeye çalışmıştır. Katılımcılar Facebook sayfalarının doğru yönetildiği sürece firma algısı üzerinde olumlu etkisinin olduğunu, firma bilinirliğini artırdığını, firma imajının oluşturulması, belli bir konuma getirilmesi ve devamlılı̆̆ı hususlarında Facebook'u oldukça önemli bulduklarını ifade etmişlerdir. Firmalar, buradan elde ettikleri geri bildirimler sonucunda üretim ve pazarlama faaliyetlerini yeniden şekillendirebilmektedir.

Sosyal medyada gıda ürünleri üzerine yürütülen pazarlama faaliyetleri etik açısından özellikle hedef kitle çocuklar ise veya söz konusu ürünlerin sağlığa zararlı etkileri var ise tartışma konusu olmaktadır. Bu pazarlama tekniğinde vurgulanması gereken nokta, etkili pazarlama stratejilerinin temel elemanının mesajın alıcıları olduğu ve iletişim sürecine aktif şekilde dahil edilmesi gerekmektedir. Sağlığa zararlı olduğu için geleneksel medyada engellenen reklamlar internet ortamında online düzenlemeler olmadığı için firmalar yürütülen kampanyalarda daha rahat hareket edebilmektedir. $\mathrm{Bu}$ değerlendirmeler açık bir şekilde sosyal medyada paylaşılan içeriklerin uygun düzenlemelerle kontrol edilmesinin gerektiğini ortaya koymaktadır.

\section{Sosyal Medyanın Gıda Krizlerinin Yönetiminde Etkisi}

Sosyal ağlar bilgi akışının daha hızlı gerçekleşmesine ve firmaların tüketici taleplerine daha hızlı yanıt vermesine olanak sağlamaktadır. Sosyal medya, kullanıcıların daha hızlı şekilde aynı anda çok çeşitli içeriğe erişebilme ve içerik paylaşım imkânına sahip olması çok sayıda kişiyi kısa bir zamanda bir araya getirebilmektedir. Başka bir ifadeyle sosyal medya anlık bilgi üretimi, paylaşımı ve etkileşimi nedeniyle gıda ürünleri ile ilgili krizlerde daha etkin rol oynamaktadır. $\mathrm{Bu}$ durum kamu kurumları ve sivil toplum kuruluşları için aynı geçerlilikte olmasa da oldukça önemlidir. Özellikle gıda güvenliği ile ilgili konular dikkate alındığında bu medya kanalından oldukça önemli sonuçlar alındığı görülmektedir. Shan ve ark., (2014) tarafından yapılan bir çalışmada İrlanda'da domuz eti ve 
ürünlerinin sağlığa zararlı unsurlar içerdiğinin belirlendiği ve bu ürünlerin dünya genelinde toplatılmasıyla ilgili yaşanan krizde, haberlerin sosyal medyada geleneksel medya araçlarına göre çok daha fazla yer aldiğ 1 ve dikkat çektiği ortaya konulmuştur. Almanya'da 2011 yılında meydana gelen gidalarda bir Ecoli bakteri türü olan Enterohemorajik Escherichia coli (EHEC) görülmesi ile ortaya çıkan krizde ise sosyal medya, daha önce daha önce rastlanılmamış olan bu organizmanın genetik yapısının belirlenmesinde oldukça büyük fayda sağlamıştır. Çinde bir laboratuar, bu zararlı yapının tanımlanması için yapılan çalışmalara liderlik etmiştir. Araştırmacılar ve Dünya Sağlık Örgütü tarafindan geliştirilen sanal forumlar dünyanın hemen her yerinden bilim insanlarının bu araştırma için bir araya gelerek bilgi sağlamasına olanak tanımıştır. Sosyal medya tarafından desteklenen bu çabaların sonucu olarak organizmanın DNA dizilimi 2 gün içerisinde elde edilmiştir (Casey ve ark., 2011). ABD, Hastalık Koruma ve Kontrol Merkezi de halk sağlığı ile ilgili uygulamalarda sosyal medyadan yararlanmaktadır. Bunun bir örneği 2009 yılında ortaya çıkan yerfıstığg içeren ürünlerde Salmonella typhimurium görülmesi ile ilgili krizde yaşanmıştır. Ürünlerin geri toplanmasının ardından merkez görevlileri bir yazılım geliştirerek internet ve sosyal medyadan toplumu haberdar ederek, bir barkod yardımıyla tüketicilerden bu ürünlerin tam olarak toplandığının kontolü ile ilgili yardım istemiştir (Tilley ve Cokley, 2008). Bu krizde sosyal medyanın kullanılması tüketicilerde oldukça büyük farkındalık yaratarak, bilgi paylaşımına toplumun da katılmasını sağlamış, böylece toplum daha geniş ve aktif şekilde kriz boyunca iletişim sürecinin bir parçası olmuştur. Ayrıca bu merkezin sosyal medyayı güçlü şekilde kullanması faydalı, güvenilir ve bilimsel bilginin topluma sunulmasında oldukça etkili olmuştur (Rutsaert ve ark., 2013).

Sosyal Medyanın farklı kullanıcıları bir araya getirebilme ve böylece sanal topluluklar meydana getirebilme özelliği herhangi bir konuda aynı anda zıt görüşlerin de ortaya çıkmasına sebep olabilmektedir. Farklı bakış açılarının kontrol edilmeden serbestçe ifade edilmesi bilgi kirliliğine yol açabilmektedir. son zamanlarda, özellikle tavuk eti tüketiminde uzman olmayan kişilerin hormon, GDO’lu yem (Genetik Yapısı Değiştirilmiş Organizmalar) ve antibiyotik kullanımınıyla ilgili söylemleri tüketicilerin tavuk üreten firmalara olan güvenini olumsuz yönde etkilemiş ve bilgi kirliliğine neden olmuştur. Bu söylemlere örnek olarak, "Tavuktan Tümör fişkırıyor" (Anonim, 2016a) ve "Tavukculuk uygulamalarına dur de" (Anonim, 2016b) gibi söylemler tüketici nazarında olumsuz algı yaratmış ve bilgi kirliliğinin ortaya çıkmasına sebep olmuştur. Ancak bu olumsuz söylemlerin ardından tavuk hakkındaki bilgileri daha kapsamlı ve anlaşılır bir şekilde açıklamalar gelmiştir. Bunlar, Tarım Bakanlığı, çeşitli araştırma kuruluşları ve üniversitelerde çalışan alanında uzman kişiler tarafindan (Anonim, 2016c; Anonim, 2016d; Anonim, 2016e) kapsamlı şekilde açıklanmış ve sosyal ağların kullanılması ile birlikte kısa zamanda bilgilerin yayılması sağlanmıştır.

Rutsaert ve ark. (2014) Avrupa'da altı ülkede (Belçika, İrlanda, İtalya, Litvanya, İspanya ve Hollanda) gıda sektöründe faaliyet gösteren firmaların yetkilileri ile yaptıkları görüşmeler sonucunda sosyal medyanın gıda ürünleri ile ilgili bilgi paylaşımında rolünü GZFT (güçlü ve zayıf yönler ile firsat ve tehditler) analizi ile ortaya koymuşlardır. Yapılan çalışma sonucunda sektörde faaliyet gösteren tüm paydaşların tamamı sosyal medyanın gıdaların faydalarını ve risklerini topluma ulaştırma açısından oldukça önemli olduğu ve bu önemin gün geçtikçe artacağı görüşündedir. Bilgi iletişiminde, bu medya kanalının güçlü yanları etkileşimin hızlı olması, güçlü farkındalık, kolay ulaşılabilirlik, teknolojik olanaklar; zayıf yanları kaynakların güvenilirliğinin düşük olması, herhangi bir filtreleme mekanizmasının olmaması, sürekli yatırıma ihtiyaç duyulması, gizlilik politikaları ile ilgili sorunlar ve olumsuz algının kolay bir şekilde yaratılması olarak belirlenmiştir. Firmaların karşılaştığ 1 fırsatlar ise spesifik hedef kitlelere kolay ulaşım, gıda krizlerde bilgi paylaşımının kolay olması, iletişim teknolojilerinin popülerliği, bir topluluğa ait olma hissi, kullanıcıların tarafsız bilgi ihtiyacının büyük olması; tehditler ise alanda bilgilerin hızlı değişmesi, aşırı bilgi paylaşımı ve bilgi kirliliği ve bazı tüketici grupları tarafindan halen geleneksel medya kanallarının tercih edilmesidir.

\section{SONUÇ}

Günümüzde tüketiciler satın alma davranışlarını şekillendirirken geleneksel pazarlama kanalları yerine dijital pazarlama kanallarını ve son yıllarda bir fenomen haline dönüşen sosyal medyayı tercih etmektedir. Sosyal medya genel olarak, sosyal bir çevre oluşturmak amacıyla kurulan, büyük kitlelerin birbirleriyle etkin olarak iletişime ve etkileşime geçebildikleri elektronik ortam olarak tanımlanmaktadır. Bu uygulamalar geniş kitlelere ulaşı1ması, kişilerin gerek birbirleri ile gerekse de firmalarla kolay şekilde bilgi paylaşımı sağlaması ve tüketici farkındalığını artırması açısından önemli katkılar sağlamaktadır. Ancak, söz konusu bilgilerin herhangi bir filtrelemeye tabi tutulmadan topluma sunulmas1, olumsuz algının yaratılmasının kolay olması ve bilgi kirliliğine yol açabilmesi gibi olumsuz özellikleri de mevcuttur.

Sosyal medya ortaya çıkardığ 1 yeni norm ve değerlerin etkisiyle tüketicilerin satın alma davranışlarını ve beslenme alışkanlıklarını etkilemektedir. Tüketiciler sosyal medya sayesinde yeme-içme deneyimlerini paylaşmakta, yorum yaparak çevresinin tercihlerini etkileyebilmekte veya çevresinin etkisiyle yeni deneyimlerin peşine düşmekte ve farklı gıdaları denemek istemektedir. Bu noktada işletmeler tüketici eğilimlerini en iyi şekilde takip etmeli ve bu eğilimlere hılı şekilde cevap verebilme yeteneğine sahip olmalıdır. İşletmeler, pazarlama faaliyetlerini sosyal medya ve sosyal müşteri ilişkileri yönetimi üzerine yoğunlaştırmalıdır.

Sosyal medyada bilgi paylaşımının geniş kitlelere ulaşabilmesi oldukça hızlı ve kolay şekilde 
sağlanabilmektedir. Ancak yayılan bilgiyi kontrol etmek zor olduğu için herhangi bir olumsuz haberde tüketiciler şiddetli tepkiler gösterebilmekte ve tepkilerin piyasaya yansıması kısa bir sürede olabilmektedir. Bu durum bazı sektörlerin ve ya işletmelerin önemli kayıplar yaşamasına sebep olabilmektedir.

Sosyal ağ siteleri, tüketicilerin hem birbirleri hem firma çalışanları ile bilgi alışverişinde bulunabilmeleri için oldukça rahat bir ortam sağlamaktadır. Bazı firmaların çalışanları yapılan yorumlara ve eleştiriler karşısında oldukça duyarlı şekilde davranırken bazı firma çalışanları yeterince hassas davranmamaktadır. Bu noktada, firmalar çalışanlarını sosyal medyanın etik kuralları ile ilgili eğitmeli ve davranışlarını garanti altına almalıdır. Medyada yer alan bilgilerin filtreden geçirilerek, doğru ve kapsamlı şekilde tüketicilere ulaştırılması geremektedir.

Sonuç olarak, sosyal medya kavramı, yeni medya araçlarını kullanarak tüketicilere ulaşılmasına ve pazarlama stratejisi oluşturulmasına olanak sağlamıştır. $\mathrm{Bu}$ durum işletmelerin ürün ulaştırmalarındaki coğrafi sınırlamaları, zaman sorununu, satış öncesi memnuniyeti ve fiyat gibi tüketici için önemli olan bu özellikleri sorun olmaktan çıkarmaktadır. Firmalar sürekli değişen ve yenilenen bu medya kanalındaki mesajları doğru okumalı ve müşterilerine en etkin pazarlama stratejilerini sunmalıdır.

\section{KAYNAKLAR}

Anonim 2016a. Yediğiniz Tavuklar Aslında...http://www.bayanlarbilir.com/yediginiztavuklar-aslinda-2059. (Erişim Tarihi:02.09.2016).

Anonim 2016b. Greenpeace Akdeniz - Türkiye. https://www.facebook.com/Greenpeace.Akdeniz.Tur kiye/posts/10154883990474517.

(Erişim Tarihi:06.09.2016).

Anonim 2016c. Piliç Eti Hakkında Doğru Bilinen Yanlışlar http://www.tarim.gov.tr/ GKGM/Belgeler/ Risk\%20De\%C4\%9Ferlendirme\%20Hizmetleri/Tuk etici_Bilgi_Kosesi/piliceti_dogru_bilinen_yanlislar. pdf. (Erişim Tarihi:05.09.2016).

Anonim 2016d. Tavuk Eti Tüketimiyle İlgili Yanlış Yönlendirmeler.

https://www.facebook.com/garipolu/posts/10154542 122884076. (Erişim Tarihi:07.09.2016).

Anonim 2016e. Prof. Dr. Bingür Sönmez: Artık Tavuktan Özür Dileme Zamanı http://www.posta.com.tr/prof-dr-bingur-sonmezartik-tavuktan-ozur-dileme-zamani-haberi-333708. (Erişim Tarihi:09.09.2016).

Algül A, Sütcü CS 2015. Değişen Haber Algısı: Kullanıcılar Sosyal Medyada Haberleri Nasıl Değerlendiriyorlar?. Global Media Journal TR Edition.6 (11).

Alyakut Ö 2016. Kartepe Örneğinde Doğal Gıda Üretimi Yapan Üre-Tüketicilerin Sosyal Medyada Üretim ve Tüketim Pratikleri. Akademik Bakış Dergisi, 57: 125 149.

Brandwatch 2016. Brandwatch Report - Social Listening In The Restaurant, Food \& Beverage Industry . https://www.brandwatch.com/wpcontent/uploads/2015/05/Social-Listening-in-theRestaurant-Food-Beverage-Industry.pdf. (Erişim tarihi: 1.11.2016)

Casey PG, Hill C, Gahan C 2011. E. coli O104: H4: Social Media and The Characterization of an Emerging Pathogen, Bioengineered Bugs, 2, $189 \mathrm{e} 193$.

Chao C, Corus C, Li T 2012. Balancing Traditional Media and Online Advertising Strategy. International Journal of Business, Marketing, and Decision Sciences, 5(1), 12-24.

Chi HH 2011. Interactive Digital Advertising VS. Virtual Brand Community: Exploratory Study of User Motivation and Social Media Marketing Responses in Taiwan. Journal of Interactive Advertising 12: 44-61.

Cmocouncil, 2015. Marketing spend. [Online] Available at: https://www.cmocouncil.org/facts---stats--categories.php?view=all\&category=marketing--spend. (Erişim Tarihi: 1.11.2016).

Cohen LS 2009. Is There a Difference Between Social Media and Social Networking? http://www.socialmediatoday.com/socialbusiness/peteschauer/2015-06-28/5-biggestdifferences-between-social-media-and-social. (Erişim Tarihi: 03.11.2016)

Cvijkj IP Michahelles F, 2013. Online Engagement Factors On Facebook Brand Pages. Springer-Verlag, 26 January. pp.843-61.

Dewing M 2010. Social Media: An Introduction - In Brief (No: 2010-03-E) Social Affairs Division. Parliament of Canada

Dykeman D 2008. How Do You Define Social Media?”. http://broadcasting-brain.com/2008/02/09/how-doyoudefine-social-media/. (Erişim tarihi: 10.11.2016).

Hartshorn S 2010. 5 Differences Between Social Media and Social Networking. Retrieved http://www.socialmediatoday.com/SMC/194754. (Erişim tarihi: 10.10.2016).

Hennig-Thurau T, Gwinner K, Walsh G, Gremler D, 2004. Electronic Word-of-Mouth Via Consumer Opinion Platforms: What Motivates Consumers to Articulate Themselves on the Internet? Journal of Interactive Marketing, 18: 38-52.

Hollensen S 2010. Marketing Management: A Relationship Approach (2nd ed.). Harlow, Essex: Pearson Education Limited.

Ioanas E, Stoica I 2014. Social Media and Its Impact on Consumers Behavior. International Journal of Economic Practices and Theories, 4(2): 295-303.

Jantcsh J 2008. Let's Talk: Social Media for Small Businesses.

https://www.ducttapemarketing.com/the-definitionof-social-media/. (Erişim tarihi: 10.11.2016)

İşler DB, Yarangümelioğlu D, Öztürk E 2014. Online Tüketici Satın Alma Davranışlarını Etkileyen Faktörlere Yönelik Bir Durum Değerlendirmesi: Isparta İlinde Bir Uygulama. Uluslararası Alanya İşletme Fakültesi Dergisi, 6(3): 77-94. 
Kaplan A, Haenlein M 2010. Users of The World, Unite! The Challenges and Opportunities of Social Media. Business Horizons, 53(1): 59-68.

Kenly A, Poston B 2011. Social Media and Product Innovation-Early Adopters Reaping Benefits amidst Challenge and Uncertainty. http://kalypso.com/downloads/insights/Kalypso_Soc ial_Media_and_Product_Innovation_1.pdf. (Erişim tarihi: 01.11.2016).

Kemp S 2016. Digital in 2016. http://www.slideshare.net/wearesocialsg/digital-in2016 (Erişim Tarihi: 21.11.2016).

Kırçova İ 2008. İnternette Pazarlama. 4. Bask1, Beta Yayım Dağıtım A.Ş. İstanbul.

Kızgın Y, Özkan B 2014. Tüketicilerin Helal Gıda Tüketim Eğilimlerinin Belirlenmesine Yönelik Bir Çalışma. Uluslararası İşletme ve Yönetim Dergisi, 2(1): 18-37.

Meier CD, Buri S, Cornuz C 2014. Generation Y, Social Networks And The Food Service Industry. Generation Y, Social Networks \& The F\&B Industry Case Study : Food Service Brands On Facebook. file:///C:/Users/Arzu\%20SECER/Downloads/fandbi ndustry-generation-y-web\%20(2).pdf.

(Erişim Tarihi: 18.11.2016).

Murphy H, Wright A 2015. An Appetite for Social Media in Irish SME Food Businesses?', Presented at the 11th Annual Tourism and Hospitality Research in Ireland

Neti S 2011. Social Media and Its Role in Marketing. International Journal of Enterprise Computing and Business Systems. Network Marketing. European Journal of Marketing. https://www.researchgate.net/publication/260908285

Nyarkoa M, Altıntaş T 2015. Social Media Marketing and a Case Study on Food Manufacturing in Ghana, ABMYO Dergisi. 38: $11-25$.

Olgun B 2015. Sosyal Medyanın Tüketici Satın Alma Davranışları Üzerindeki Etkisi. Gümüşhane Üniversitesi, Sosyal Bilimler Elektronik Dergisi. 12: 484-507.

Özgen E, Doymuş H 2013. Sosyal Medya Pazarlamasında Farklılaştırıcı Bir Unsur Olarak İçerik Yönetimi Konusuna İletişimsel Bir Yaklaşım. Online Academic Journal of Information Technology. 4(11): 91-103.

Paquette H 2013. Social Media as a Marketing Tool: A Literature Review. http://digitalcommons.uri.edu/tmd_major_papers/2. (Erişim Tarihi: 17.11.2016).

Parr B 2008. Ben Parr's Entrepreneurial Musings. http://benparr.com/2008/08/its-time-we-definedsocial-media-no-more-arguing-heres-the-definition/ (Erişim Tarihi: 15.11.2016).
Punj G 2011. Effect of Consumer Beliefs Online Purchase Behavior:The Influence of Demographic Characteristics and Consumption Values. Journal of Interactive Marketing, 25(3):134-144.

PwC 2013. Online Alışveriş Yapanların Gizemi Çok Kanalli Perakendecilikte $10 \quad$ Mit. https://www.pwc.com.tr/tr/publications/industrial/ret ail-consumer/pdf/online-alisveris-yapanlaringizemi.pdf . (Erişim Tarihi: 20.11.2016).

Rutsaert P, Reganb A, Pieniaka Z, McConnonb A, Mossc A, Wallb P, Verbekea W 2014. The Use of Social Media in Food Risk and Benefit Communication. Trends in Food Science \& Technology 30: 84-91.

Say S 2015. Pazarlama Araci Olarak Sosyal Medya Kullanimi: Gida Sektöründe Facebook Örneği. İstanbul Aydın Üniversitesi Dergisi, 7(28): 19-39.

Sema P 2013. Does Social Media Affect Consumer Decision-Making?MBA Student Scholarship. Paper 24. http://scholarsarchive.jwu.edu/mba_student/24. (Erişim Tarihi: 15.9.2016).

Shabnam, S., Choudhury, A. ve Alam, M. I., 2014. An Emerging Method of Communication: Social Media Marketing and It's Social and Managerial Implications. World Review of Business Research, 3(1): 1-25.

Shan L, Regan Á, De Brún A, Barnett J, Van der Sanden M, Wall P, McConnon Á 2014. Food Crisis Coverage by Social and Traditional Media: A Case Study of the 2008 Irish Dioxin Crisis. Public Understanding of Science. 23(8): 911-928.

Tilley A, Cokley J 2008. Deconstructing the discourse of citizen journalism: who says what and why it matters, Pacific Journalism Review. 14:94-114.

Toksarı M, Mürütsoy M, Bayraktar M 2014. Tüketici Algılarını Etkileyen Faktörlerde Sosyal Medyanın Rolü: Niğde Üniversitesi İ.İ.B.F. Örneği. Uşak Üniversitesi Sosyal Bilimler Dergisi 2014, 7/4.

Vukasovič T 2013. Brand Developing Relationships Through Social Media. Management, Knowledge and Learning International Conference, 19-21 June, Croatia.

Yıldız Y 2014.Tüketici Davranışları Üzerinde Sosyal Medya Etkileri: Apple ve Samsung Örneği. Kastamonu Üniversitesi Iktisadi ve Idari Bilimler Fakültesi Dergisi. 1(4): 5-15

Yücel N 2013. Müşteri İlişkileri Yönetimi’nde Yeni Bir Anlayış: Sosyal Müşteri İlişkileri Yönetimi. The Journal of Academic Social Science Studies International Journal of Social Science, 6(1):16411656. 